\title{
Specific Features and Language Components of English Used by EFL Learners in Sundanese Cultural Context: A Case in a Paper Presentation Class
}

\author{
Erlina Zulkifli Mahmud \\ Fakultas Ilmu Budaya, Universitas Padjadjaran \\ Jatinangor, Indonesia \\ erlina@unpad.ac.id
}

\author{
Taufik Ampera \\ Fakultas Ilmu Budaya, Universitas Padjadjaran \\ Jatinangor, Indonesia \\ taufik.ampera@unpad.ac.id
}

\begin{abstract}
What had happened to EFL learners now in our country needs to be reviewed and evaluated far back to the first learning process in their Elementary School or Junior High School. The language skills given in this level are focused more to Reading and Writing with Grammar as the core. EFL learners in Indonesia are not given the Speaking skill the same portion as other skills. Speaking is given later in the next level like in the upper grade of Junior High School or even in Senior High School. This is the major reason why most Indonesian students are not well-trained in speaking and this situation continues to the next level of education, higher education, and it is getting more complicated with the influence of their cultural background. In the EFL learning process, the culture background of a learner may cause a certain effect that can be challenging to fix it. This influence becomes significant in speaking classes like Paper Presentation class which is given in the fourth semester in English Studies of Faculty of Cultural Sciences, Universitas Padjadjaran. The way they speak, how they express themselves in English, what vocabularies they choose are influenced by their culture. They use specific features from their culture in their presentation and they use language components of English as the direct equivalents taken from their Sundanese words that leads to a total misunderstanding and confusing to their audience from other culture background.
\end{abstract}

Keywords-EFL learners, speaking skill, Sundanese cultural background

\section{INTRODUCTION}

Culture is an eye to the world where all could see how other people live their life; their customs and traditions, their communication, their beliefs, their ways to respect others. Through culture people could learn the universal characteristics as well as unique characteristics of what others do in a certain society. With culture people want others to understand them that they are what they are. To get this understanding from others, it is important to communicate these to others outside of their culture and, to do this, people need to be able to communicate in other languages, the languages where most people speak, the international languages, and one of them is English.

As people need to be understood, people need to be able to communicate well based on rules of the language they are speaking. Unfortunately, the culture they would like others to understand, the culture they are born with sometimes becomes one of the problems, the challenges they need to deal with first. That is what is happening in Paper Presentation class, English Studies, Faculty of Cultura Sciences, Universitas Padjadjaran. With the Sundanese cultural background, EFL learners of this culture need to have a great effort to adapt with the English rules as well as to get rid of the culture they have been with as long as their life. It is important to make the EFL learners of this culture understand that when they are speaking in English they need to come out from their culture in order to obey the rules in English. They cannot bring all the language components and specific features they believe appropriate as showing politeness in Sundanese culture into English in a certain situation in order not to create a misunderstanding.

The data for this research are taken from Paper Presentation class. It is actually a speaking class which is a part of language skills. It is a two credit semester subject given in the fourth semester where students are required to give an oral presentation about a certain topic they copy from a written source or they make it themselves. In this class students are equipped with a Power Point Presentation. Students have a ten-minute presentation followed by a discussion for another ten to fifteen minutes. While one student is giving a presentation, other students make a written comment on their friend's presentation including pronunciation mistakes, grammatical mistakes, vocabularies, the overall presentation, and suggestions for a discussion session. This class consists of students not only from Sundanese culture but also from other cultures in Indonesia so the communication occurs inside and outside the class is basically intercultural. The utterances and specific features used by Sundanese students in this Paper Presentation class are taken as the object of this research. How the Sundanese cultural background becomes the challenges for the EFL learners of this culture in communicating their ideas so others could understand them despite of their culture background is the reason why this paper is written.

There are two previous researches that can be related to this article. Mulyana [5], one of the scholars in communication from Universitas Padjadjaran says that intercultural communication includes the meaning of symbols as well as index thus in the practice of communication, the two signs, when used by human are often complementary. He then says that the concept of communication in an intercultural communication is a humanistic concept (two ways, transactional, interactional instead of one way communication concept (linear), mechanistic (communication as a transmission), or simply as an interaction signed by stimulus-response. Mulyana describes intercultural communication in the concept of communication in general not specific with the use of any foreign language. The next research is done by Rahayu, Literature major in 
Faculty of Cultural Sciences, Universitas Padjadjaran. She focuses on the complexity of intercultural communication in Play as the tradition of translating play in Indonesia. Rahayu [4] states that the existence of intercultural communication concept basically reveals a principle that cultures do not exactly go hand in hand peacefully, it causes a friction, interaction, and exchanging ideas. This explains what had happened in the Paper Presentation class.

\section{METHOD}

As Paper Presentation is a part of speaking skill, one of the four language skills given when learning a foreign language, the theories used for this paper are of this area and supported by theories about culture, particularly Sundanese culture. What are the goals aimed in a speaking skill class can be referred to Jakeman and Mc.Dowell's [2]. For the purpose of this research, we will just focus on some of the abilities included in the speaking skill they mentioned; the ability to communicate fluently, to communicate on general topics, to give opinion backed by reasoned argument, to ask question. These all can be achieved in Paper Presentation class as in this class, EFL learners are taught to communicate fluently in order to be understood by others, they are taught to communicate on general topics as in the topics they choose to present, and as their presentation will deal with some objective data, they are taught to give opinion backed by reasoned argument, and as there is a discussion session after the presentation, they are taught to answer as well as to ask questions.

What steps needed so the presentation goes smoothly and be understood by the audience can be viewed from this internet website [8] downloaded on March $26^{\text {th }}, 2017$. Some of them which directly relate to the issue discussed here are as follow; focus on your audience's needs, smile and make eye contact with your audience, start strongly, use your voice effectively, use your body too. It has been estimated that more than three quarters of communication is non-verbal. Make your gestures open and confident, and move naturally around the stage and among the audience too, if possible.

All the abilities and tips can be easily achieved relatively when there is no interference from a certain culture background, a local culture as happened in the Paper Presentation class with EFL learners of Sundanese cultural background. Sundanese culture is a local culture existed in West Java. According to the Anthropology of Culture in Koentjaraningrat's [3], what is called as Sundanese ethnic is those who from generation to generation speak Sundanese language and its dialects in their daily life as their mother tongue, and they come from West Java originally and they live there, a place where it is also called Tanah Pasundan or Tatar Sunda.

The importance of Sundanese culture reflected in Sundanese language can be viewed from their philosophies that Sundanese people see the importance of a human being as a person who is represented by their behaviors, by their words when speaking. Some of the philosophies are as follow; "kudu hade gogog, hade tagog" it shows that Sundanese people have to have a good tact and behave well, and this is strengthened by other philosophy "nyaur kudu diukur, nyabda kudu diungang" which means that Sundanese people have to be able to control themselves when speaking to others [1]. What Sundanese people own in their culture includes some basic personalities as quoted from Suryalaga [7] that Sundanese people are wanter (dare to express themselves, confident) and interdependency without losing their personalities. These characteristics representing Sundanese people which among others, can be seen particularly when speaking to elderly people;

(a) they avoid eye contact during a conversation: they believe that eye to eye contact will lead to a misunderstanding, staring at, which is not polite,

(b) keeping a distance, mostly one step away: this allows them to bow slightly, to make them a bit lower than the elderly people they are talking to in order to show respect,

(c) nodding frequently: they do this to show that they understand what are being told to, that they pay attention to what the elderly people say to them,

(d) saying "muhun" (sumuhun) 'yes' repeatedly to show that they pay attention and they understand

(e) saying "punten" 'excuse me' which contains basically a semantic component of politeness, asking for an apology for interrupting others' activities,

(f) sometimes Sundanese people rub their left elbow up and down with their right hand while bowing a bit not to show awkwardness but just to be humble to the elderly people they are talking to in a relaxing manner.

The situation in the Paper Presentation class shows a form of intercultural communication as the students there are from various cultural backgrounds and this becomes challenging as the students use foreign language to communicate each other.

The research method used to collect the data for this paper is categorized into a case study; it is a field study which is done through observation. One of the characteristics of this method according to Suryabrata [6] is that a case study penelitian kasus is an intensive research about a certain social unit which aims to get a complete and well organized description of the unit'. Suryabrata who combines a case study with field research adds that the goal of this method is to study intensively about the background of a current situation, and environmental interactions of a certain social unit; individual, group, institution, or society. The certain social unit which becomes the object of this research is EFL learners with Sundanese cultural background in a Paper Presentation class. The goal of this research is to get a complete and well organized description of what had happened during Paper Presentation class so some necessary actions to overcome the situation can be implemented.

\section{FINDING AND DISCUSSION}

\section{Specific Features Used by EFL Learners of Sundanese Cultural Background}

There are some specific features used by Sundanese EFL learners in Paper Presentation class, a body language, gestures. They do these naturally as a part of showing respect to others 
as taught in their culture. Despite strengthening information delivered in a presentation, the body language used by EFL learners with Sundanese cultural background results something else; opposite to the target it needs to achieve. Students from other cultures see these differently when applied to English context.

\section{Not Having An Eye Contact}

Some EFL learners with Sundanese cultural background speak to their lecturer without having an eye contact. They do try to have an eye contact but mostly just for a few seconds when they start their conversation, then quickly lower their heads, and usually the rest of the time they just keep staring at the floor. They do this not because they are not confident with their presentation, and not because they are not polite, instead, it is a way to respect others especially elderly people in their culture. They are aware that this cannot be accepted when they are speaking in English yet they still believe that it is not right to maintain an eye contact with elderly people, especially their lecturer. This can be understood differently if they do it when speaking to a native speaker or a foreigner. This is a challenge they need to overcome if they want others to understand them particularly in inter-cultural communication like in Paper Presentation class. Fortunately they do not do this when they are speaking to their friends, people of the same age. They will maintain the eye contact in the discussion when they need to respond the questions or comments from their classmates.

\section{Keeping a Distance One or Some Steps Away}

Having no eye contact is very often added by keeping a distance one or some steps away when talking to a lecturer. This is a way to make a space so they could bow slightly during a conversation to show that they understand what the lecturer is talking about, responding to any comment. And over all this is also a way to show respect to elderly people. This may not result negatively as showing formality by keeping a distance (without bowing) is familiar in other cultures including English. However when this is done at the time to open a presentation in front of the class, this can distract others' attention, other EFL learners as the real audience, and this cannot be considered as a strong opening to the presentation.

\section{Nodding Frequently}

In Sundanese culture, nodding frequently during a conversation is common; it is a way to show that you pay attention to what the addressee's talking about. Usually it is accompanied by a constant response in an utterance "muhun" showing a form of agreement like "noted" or "understood" or "okay" or simply "yes". Sundanese EFL learners do this naturally in the class during their presentation at mostly every pause the addressee's make when talking to them. This may not indicate something serious yet it can be considered as over-reacting to others.
Rubbing Left Elbow Up And Down with the Right Hand When having no eye contact, staring at the floor, can be misunderstood as a form of impoliteness, rubbing left elbow up and down with the right hand while having a conversation with a lecture can be considered as something else, awkwardness. This can be true but not totally true in Sundanese culture as this can also show that it is a combination way (bowing a bit and nodding frequently) to show humbleness not in a very formal way. There has not been any research about this yet or any literature references so far; why rubbing left elbow, why up and down. At first, I thought it was only individual but then this specific feature also done by some others from the same cultural background. I asked them why they did that their answers were similar that they just did that naturally, keeping them to be looked low profile. When this happens in the Paper Presentation class, it can be misunderstood by EFL learners from other cultures as being awkward and not having confident.

\section{Language Components of English Used by EFL Learners of Sundanese Culture Background}

Sundanese EFL learners not only use specific features as gestures or body language in their presentation but also use some language components of English which directly translated from Sundanese language by not choosing the right equivalent and without paying attention to the context. This may lead to a misunderstanding and confusing.

\section{Saying "I am sorry"}

EFL learners with Sundanese culture background often say "I am sorry" to begin a presentation as in the following example: "I am sorry I would like to give my presentation now" which is not common in English context. It is actually a translation from "Punten, Abdi bade ngadugikeun presentasi abdi ayeuna." "I am sorry" there is the equivalent of "punten" in Sundanese language which should be translated into 'Excuse me'. "Punten" is an expression of politeness, mostly used when the speaker needs to get the addressee's attention, asking for a permission to do something in a polite way, or for an interruption. Sundanese people use this expression most of the time naturally not only to elderly but also to anybody else. However as it is being applied in English context, the expression of "I am sorry" there could be misinterpreted as asking for an apology where others could not see for what reasons the apology there is asked. This will lead to a misunderstanding and confusing. The students need to see that there is a difference between the expression of "I am sorry" and the expression of "Excuse me".

\section{Saying "Maybe" Frequently}

"I am sorry. Maybe I may start my presentation now?" is equivalent to 'Punten. Panginten, abdi tiasa ngadugikeun presentasi abdi ayeuna?' Again the expression "I am sorry" as the equivalent of "punten" which is meant for showing a polite way as needed to get the addressee's attention is used. It is followed by the word "maybe" as the equivalent to "panginten". Literally the word "panginten" covers the 
meaning of possibility yet in Sundanese culture it is also used as a polite way to express a suggestion which does not mean doubtfulness or possibility. In that context it is actually used to express a polite way to initiate a request to do something or suggestion to do something as equivalent to English context "I wonder if I can start my presentation now." However when it is translated not properly as stated above, the expression of "maybe" adding to the expression "I am sorry" there can be confusing as it is used in a context when actually everything is fixed and apology is not needed.

\section{Saying "Yes" Repeatedly}

"Yes" used by EFL learners of Sundanese cultural background is not always to respond a yes-no question; it is a way to show attentiveness; it is equivalent to Sundanese language "muhun". Look at the following situation:

A (student with other cultural backgrounds): "Excuse me"

B (student with Sundanese cultural background): "Yes." ('muhun')

A: "I am ...er.."

B (interrupting when there is a short pause):" Yes." ('muhun')

A (distracted by the interruption, then repeating from the beginning): "I am just curious..."

B: "Yes." ('muhun')

A: "Do you think..."

B (interrupting when there is a short pause): "Yes." ('muhun')

A (distracted by the interruption, then starting from the beginning again): "Do you think the hoax in the media is tolerable?"

B: "Yes." ('muhun')

A (confusing with the response in a short pause of B's part): "Yes?"

B (then continue responding to the yes-no question): "No." A (confused): ?????

The expression of "yes" in that context which actually to show a polite way indicating an attentiveness becomes confusing as it is followed directly with "No" which indicates the opposite meaning of "yes" as the real response to the question. For others in different cultural background this can be misinterpreted as doubtfulness.

\section{Saying "Please"}

The expression of "please" used by EFL learners with Sundanese cultural background is actually the equivalent of a Sundanese language "mangga" 'alright' or 'okay' or 'please'. It is a polite expression used to show agreement to do something or to give permission to do something or just a polite way to respond "punten" 'excuse me' as in the following situations:

A: "I think you should add the information with a graph."

B (agreed to do it): "Yes, please." ('Muhun, mangga.')

A (confused): "What do you mean by "yes, please"? You are the one who supposed to do that."

B: "I meant "yes, please, I will do it."
The expression of "please" in that context actually shows that the speaker agrees to do it as in English context "Okay" or "Alright" or simply "Yes" as the equivalent to the word "mangga." However as it is not correctly translated, this can be misinterpreted as a request, to ask someone to do something politely which is not proper in the above context.

\section{CONCLUSION AND RECOMMENDATION}

What becomes expressions and gestures of politeness in Sundanese cultural background when applied into English using inappropriate vocabularies or context may lead to a misinterpretation and a confusion. This is not to be put as a serious problem to solve when we can make it into a challenge which needs to manage through more practices or by modifying a teaching method in a way that it can still adopt local cultures without resulting in misinterpretation. Those features and language components representing Sundanese culture can be made into opportunities which may strengthen EFL learners to develop in the English context without losing their personalities. The intercultural communication in a class is more challenging when the participants need to use foreign language as sometimes the context they apply may show a different situation.

\section{References}

[1] Garna, Judistira K. "Budaya Sunda: Melintas Waktu Menantang Masa Depan," Bandung: Lembaga Penelitian Unpad dan The Judistira Garna Foundation, pp.62- 65, 2008.

[2] Jakeman, Vanessa and Mc.Dowell, Clare. "Insight into IELTS". Cambridge: Cambridge University Press, pp. 96, 2001.

[3] Koentjaraningrat. "Manusia dan Kebudayaan di Indonesia." Jakarta: Djambatan, pp. 307, 2007.

[4] Rahayu, Lina Meilinawati. "Interkulturalisme dalam Drama: Tradisi Penerjemahan Drama di Indonesia," Bandung: CV Semiotika dan Sastra Unpad Press, pp. 29-30, 2014

[5] Mulyana, Deddy. "Komunikasi Efektif; Suatu Pendekatan Lintasbudaya,” Bandung: PT Remaja Rosdakarya, pp. 4-7, 2004.

[6] Suryabrata, Sumadi. "Metodologi Penelitian," Jakarta: PT RajaGrafindo Persada, pp. 80, 2014.

[7] Suryalaga, Hidayat, H.R. "Kasundaan. Rawayan Jati," Bandung: Wahana Raksa Sunda, pp. 13-14, 2014.

[8] Top Tips for Effective Presentations". https://www.skillsyouneed.com. 